\title{
PENGARUH BUDAYA ORGANISASI DAN KOMUNIKASI ORGANISASI TERHADAP KINERJA KARYAWAN PT. $X$
}

\author{
JUJUNG DWI MARTA, DEWIE TRIWIJAYANTI \\ Jurusan Manajemen, Fakultas Ekonomi, Universitas Negeri Surabaya \\ Kampus Ketintang, Surabaya 60231 \\ E-mail: jujungdwimarta30@gmail.com
}

\begin{abstract}
The purpose of this study was to analyze the influence of organizational culture and communication organizations on employee performance. Samples of this study was sampled every part of the whole section in the PT. X Surabaya which numbered 80 from a population of 500. The data analysis technique used is multiple linear regression analysis with SPSS 20 software.
\end{abstract}

Keywords: organizational culture, organizational communication, employeeperformance

\section{PENDAHULUAN}

Lingkungan bisnis dewasa ini yang tumbuh dan berkembang dengan sangat dinamis, terdapat perubahan yang menuntut penyesuaian diri yang cepat terhadap perubahan dan dapat memanajemen perubahan yang terjadi dengan tepat, cepat, dan terarah dengan tujuan meningkatkan kinerja karyawan (Brahma dan Suprayetno,2008).

Kinerja menurut Hamdi (2014:30) adalah sesuatu yang dikerjakan atau produk/jasa yang dihasilkan dan diberikan oleh seseorang atau sekelompok orang yang menunjukkan sasaran kinerja yang dicapai. Ruky (2001:18) berpendapat bahwa, kinerja pada dasarnya adalah proses kerja yang dilakukan atau tidak dilakukan karyawan, kinerja karyawan mempengaruhi seberapa banyak mereka memberi kontribusi kepada organisasi.

Budaya organisasi sendiri menurut Ghasemi (2013) adalah struktur adat, tradisi, adat istiadat, norma dan etika yang turun menurun digunakan diantara karyawannya dalam organisasi. Banyak kesuksesan yang bisa diraih suatu perusahaan karena didukung oleh sebuah budaya yang khas dan kuat tertanam dalam kegiatan operasionalnya.

Penelitian dari Wirda dan Azra (2007) menyatakan bahwa budaya organisasi berpengaruh positif terhadap kinerja karyawan. Selanjutnya penelitian dari Sunadji dkk (2013) menunujukkan bahwa budaya organisasi berdampak langsung terhadap kinerja karyawan. Hasil penelitian tersebut mendukung toeri Moeljono (2005:26) yang menyatakan bahwa budaya organisasi atau budaya korporat berpengaruh terhadap kinerja karyawan. Tetapi hasil penelitian berbeda dari Lina (2014) menyatakan bahwa budaya organisasi berhubungan tidak signifikan atau negatif terhadap kinerja karyawan. Dari hasil penelitian tersebut ditemukan research gap atau perbedaan antara hasil penelitian- 


\section{Jujung Dwi Marta dan Dewie Triwijayanti - Pengaruh Budaya Organisasi ...}

penelitian terdahulu tentang pengaruh budaya organisasi terhadap kinerja.

Budaya organisasi di perusahaan adalah budaya Muranogurupu yaitu budaya tradisional jepang yang berbasis berpikir secara kelompok, budaya tersebut dikategorikan dalam tiga bentuk umum yaitu pertama, "kemampuan untuk bekerjasama adalah penting" Kedua, "tidak ada atas dan bawah dalam bekerja", Ketiga, budaya organisasi "satu perusahaan seumur hidup".

Budaya tersebut dibentuk dan dipertahankan oleh perusahaan untuk mencapai tujuan perusahaan yaitu inovasi terus menerus dengan keberanian mengambi resiko yang didukung oleh orientasi dari orang, tim, hasil serta ketelitian untuk mendapat kinerja yang maksimal, akan tetapi budaya yang baik tersebut tidak diimbangi dengan kinerja yang baik terlihat dari menurunya hasil kerja dan tingkat absensi yang tinggi.

Selain budaya organisasi sebagai alat untuk mendapatkan kinerja yang maksimal dari karyawan, perusahaan juga memperhatikan tentang komunikasi organisasi karena perusahaan sadar betul kinerja yang baik sangat ditentukan oleh komunikasi yang baik antar karyawan maupun antar karyawan dengan pimpinan dalam pekerjaan maupun hal-hal lain diperusahaan. Untuk mendukung komunikasi organisasi yang ada diperusahaan, perusahaan memperhatikan komunikasi antar karyawan, komunikasi atasan ke bawahan dan bawahan ke atasan, agar hasil dari komunikasi organisasi karyawan dapat tercapai, karena selama ini komunikasi organisasi diperusahaan dirasa kurang.

Setiap organisasi, komunikasi organisasi mempunyai peranan sentral. Ini terutama berlaku dalam efektifitas organisasi. Proses dan pola komunikasi merupakan sarana yang diperlukan untuk mengkoordinasi dan mengarahkan kegiatan karyawan ketujuan dan sasaran organisasi. Komunikasi organisasi terdiri persepsipersepsi atas unsur-unsur tersebut terhadap komunikasi. Pengaruh ini didefinifisikan, disepakati, dikembangkan, dan dikokohkan secara berkesinambungan melalui interaksi dengan anggota organisasi lainya. Pengaruh ini menghasilkan pedoman bagi keputusan-keputusan dan tindakantindakan individu dan mempengaruhi pesan-pesan mengenai organisasi (Pace dan Faules, 1998:149).

Penelitian dari Akbar (2015) hasil penelitian ini menyebutkan bahwa komunikasi organisasi berpengaruh signifikan positif terhadap kinerja. Namun, penelitian lain yang dilakukan oleh Prabawa (2013) menunjukkan

bahwa komunikasi organisasi tidak berpengaruh secara signifikan terhadap kinerja. Penelitian dari kedua peneliti tersebut menunjukkan adanya research gap antara komunikasi organisasi terhadap kinerja karyawan sama halnya dengan reseach gap yang terjadi pada budaya organisasi terhadap kinerja karyawan yang membuat peneliti ingin melakukan penelitian lebih lanjut.

Dari budaya organisasi dan komunikasi organisasi tersebut 


\section{BISMA - Bisnis dan Manajemen -Volume 8 No. 2 Februari 2016}

diharapkan kinerja karyawan yang baik dapat tercapai, perusahaan sendiri dapat melihat keberhasilan budaya organisasi dan komunikasi organisasi di PT. X Surabaya dengan melihat kinerja karyawan yang diukur dengan hasil kinerja yang didalamnya terdapat jumlah output yang telah ditentukan dalam satu periode apakah sudah tercapai, kualitas dari output itu sendiri apakah sudah sesuai standard yang telah ditentukan dan waktu pencapaianya apakah sudah sesuai target atau belum, kemudian dari tingkat absensi karyawan dan kerjasama antar karyawanya dalam menyelsaikan suatu tugas dari perusahaan, dari itu semua perusahaan akan tau hasil dari kinerja karyawanya.

Penjelasan tentang budaya organisasi di perusahaan tersebut dapat disimpulkan bahwa budaya dari perusahaan sangat menekankan pada kerja sama tim atau team work sehingga setiap karyawan harus bersikap kooperatif untuk mau membuka diri bekerjasama dalam setiap tugas yang diberikan. Dengan kerjasama tersebut perusahaan bertujuan untuk tetap meningkatakan kinerja dan hasil kerja karyawan untuk membantu perusahaan tetap eksis didunia bisnis dengan inovasiinovasi dan kualitas dari perusahaan.

Berdasarkan latar belakang yang telah dijabarkan,hal tersebutlah yang menjadi dasar ketertarikan peneliti dalam mengambil judul penelitian"Pengaruh Budaya Organisasi dan Komunikasi Organisasi Terhadap Kinerja Karyawan Bagian Produksi PT. X".

\section{KAJIAN PUSTAKA \\ Budaya Organisasi}

Definisi budaya yang dikemukakan oleh Moeljono,2006: 17 merupakan produk konteks pasar di tempat organisasi beroperasi, peraturan yang menekan, dan sebagainnya. Selain itu, budaya juga merupakan produk struktur dan fungsi yang ada dalam organisasi, misalnya organisasi yang tersentralisasi berbeda dengan organisasi yang terdesentralisasi. Dan yang terakhir, budaya organisasi juga didefinisikan sebagai produk sikap orang-orang dalam pekerjaan mereka, hal tersebut berarti produk perjanjian psikologis antara individu dengan organisasi.

Suyanto, 2007: 217 mendefinisikan budaya organisasi sebagai program pemikiran secara kolektif yang membedakan para anggota suatu organisasi dari organisasi lainnya. Budaya organisasi memiliki pengaruh kuat terhadap perilaku karyawan. Budaya organisasi ini dapat membentuk lingkungan yang destruktif atau konstruktif dalam sebuah perusahaan sehingga meningkatkan kinerja karyawan dan kenyamanan dalam bekerja (Safaria, 2004:9).

Budaya organisasi yang didefinisikan oleh Edgar H. Schein (dalam Tangkilisan, 2007:15) yaitu sebagai pola asumsi dasar bersama yang dipelajari oleh kelompok dalam suatu organisasi sebagai alat dalam memecahkan masalah terhadap penyesuaian faktor eksternal dan integrasi faktor internal, dan telah terbukti sahih, dan selanjutnya diajarkan kepada para anggota organisasiyang baru sebagai cara untuk 


\section{Jujung Dwi Marta dan Dewie Triwijayanti - Pengaruh Budaya Organisasi ...}

mempersepsikan, memikirkan, dan merasakan dalam kaitannya dengan masalah yang dihadapi.

Berdasarkan berbagai pendapat dari para ahli, dapat disimpulkan bahwa budaya organisasi merupakan sebuah nilai yang dianut oleh seluruh karyawan dalam sebuah organisasi. Dimana setiap karyawan harus memahami karakteristik budaya organisasi diperusahaan, ciri khas dari suatu organisasi tersebut untuk menunjang kinerja karyawan sehingga manfaat budaya organisasi sebagai faktor konstruktif suatu perusahaan atau organisasi dalam meningkatkan kinerja karena merasa nyaman dalam bekerja dengan adanya.

Budaya organisasi memiliki empat tipe budaya sebagaimana yang dikemukakan oleh Cameron dan Quinn (dalam, Rangkuti, 2011: 33) yaitu (1) Clan Culture, (2) Adhocracy Culture, (3) Market Culture, (4) Hierarcy Culture.budaya organisasi dapat tercapai.

Robbins dan Judge (2008:256)ada tujuh karakteristik utama yang secara keseluruhan, merupakan hakikat kultur sebuah organisasi (1) Inovasi, (2) Perhatian terhadap hal detail, (3) Orientasi hasil, (4) Orientasi orang atau individu, (5) Orientasi tim, (6) Agresifitas, (7)Stabilitas.

Indikator yang digunakan dalam penelitian ini menggunakan indikator yang didasarkan pada karakteristik budaya organisasi dari Robbins dan Judge (2008:256), hal tersebut didukung dengan penelitian sebelumnya yang menggunakan karakteristik budaya organisasi sebagai indikator budaya organisasi yaitu Robbins dan judge dalam (Soedjono 2005, Herlista (2013), Widagdo dkk,2013, Arianty 2014, Zunaidah 2014, Gultom 2014, Akbar 2013,Rojuaniah 2012, Johannes dan Silitonga 2013)

\section{Komunikasi Organisasi}

Keseharian proses komunikasi pasti selalu terjadi baik komunikasi antar individu maupun dalam kelompok atau organisasi. Dalam perusahaan atau organisasi jika melakukan suatu proses komunikasi juga akan dipikirkan mengenai dampak maupun efek yang akan terjadi nantinya. Adapun dampak yang berhubungan dengan organisasi adalah dampak behavioral, yakni dampak yang timbul pada komunikasi dalam bentuk perilaku, tindakan, maupun kinerja seseorang (Effendi, 2000:7).

Pengertian dari komunikasi organisasi menurut Wayne (2001:143) didefinisikan sebagai pertunjukkan dan penafsiran pesan diantara unit komunikasi yang merupakan bagian dari suatu organisasi. Didalam sebuah teori dalam komunikasi organisasi (Pace dan Faules, 1998:145), dikemukakan bahwa keputusan yang diambil oleh anggota organisasi untuk melakukan pekerjaan secara efektif, untuk bersikap jujur pada organisasi, untuk meraih semangat dalam organisasi, untuk melaksanakan tugas secara kreatif dan untuk menawarkan gagasan yang inovatifbagi penyempurna organisasinya adalah dipengaruhi oleh sebuah komunikasi.

Pembahasan tersebut membuat penulis dapat menyimpulkan bahwa komunikasi organisasi merupakan 


\section{BISMA - Bisnis dan Manajemen -Volume 8 No. 2 Februari 2016}

proses yang paling penting, karena jika tidak ada komunikasi organsasi yang baik maka pesan yang merupakan bagian dari organisasi tidak akan dapat tersalurkan dengan baik. Dan dari komonikasi organisasi pula semua karyawan yang ada dapat memahami segala halyang ada.

Penjelasan yang telah dikemukakan tersebut selanjutnya dirangkum oleh penulis bahwa komunikasi organisasi adalah proses yang terjadi dalam suatu organisasi, dan dalam proses komunikasi yang terjadi terbagi dalam tiga aspek, yaitu komunikasi vertical atas ke bawah, komunikasi vertical keatas kebawah, dan komunikasi horizontal atau dikatakan komunikasi yang terjadi antara rekan sekerja dalam organisasi tersebut.

Komunikasi organisasi memiliki beberapa jenis komunikasi organisasi yaitu (Arni, 2007:107):

1. Komunikasi vertical dari atas

kebawah

Komunikasi yang dijalankan dengan ciri utama informasi mengalir dari jabatan yang lebih tinggi kepada yang lebih rendah.Umumnya jenis informasi yang disampaikan sangat erat kaitanya dengan aktifitas kerja yang harus dilakukan anggota organisasi.Bentuk umum dari komunikasi dari atas kebawah. Secara umum komunikasi kebawah dapat diklasifikasikan atas lima tipe :

a. Instruksi Tugas

Menyatakan definisi instruksi tugas sebagai berikut "pesan yang disampaikan kepada bawahan mengenai apa yang diharapkan melalui apa yang dilakukan mereka dan bagaiman cara melakukanya

b. Rasional

Menyatakan definisi rasional pekerjaan sebagai berikut: "Pesan yang menjelaskan mengenai tujuan aktivitas dan bagaiman kaitan aktivitas itu dengan aktivitas lain dalam organisasi atau obyek organisasi".

c. Idiologi

Menjelaskan bahwa idiologi adalah perluasan dari pesan rasional. Dimana pada pesan rasional penekananya ada pada penjelasan tugas dan kaitanya perspektif orgnaisasi, sedangkan pada pesan idiology sebaliknya mencari sokongan antusias dari anggota organisasi guna mendapatkan loyalitas, moral, dan motivasi.

d. Informasi

Informasi dimaksudkan untuk memperkenalkan bawahan dengan praktek organisasi, perturan organisasi, keuntungan, kebiasaan dan data lain yang tidak berhubungan dengan instruksi dan rasionalitas.

e. Balikan

Balikan adalah pesan yang berisi informasi mengenai ketepatan individu melakukan pekerjaannya.

2. Komunikasi vertikal dari bawah ke atas

Fungsi yang dijalankan pada model bottom uplebih menekankan bagaimana bawahan memberikan respon atas kebijakan yang ditentukan oleh 


\section{Jujung Dwi Marta dan Dewie Triwijayanti - Pengaruh Budaya Organisasi ...}

organisasi (Ruben 2004). Memberikan fungsi yang diberikan dari bawahan ke atasan berguna untuk memberikan input dalam proses pengambilan keputusan organisasi, memberikan pertimbangan apa yang perlu dilakukan bawahan untuk dapat menyelesaikan pekerjaan secara optimal, memberikan pertimbangan kepada pemimpin untuk membuat keputusan yang tepat dalam menyelesaikan suatu masalah ataupun membuat kebijakan. Tujuan dari komunikasi ini adalah untuk memberikan balikan atau feed back, saran, dan mengajukan pertanyaan yang pada kenyataanya komunikasi ini merupakan komunikasi dua arah .

3. Komunikasi Horizontal

Inti dari komunikasi horizontal lebih mengedepankan pada penyampaian informasi kepada orangorang yang berada pada level atau otoritas yang sama/sederajat. Komunikasi horizontal memiliki fungsi memperlancar aktifitasorganisasi dalam melakukan koordinasi perencanaan dan pelaksanaan tugas-tugas yang harus diselesaikan, menyelesaikan permasalahan yang harus dihadapi bersama, memfasilitasi tercapainya pemahaman bersama atas perbedaan yang muncul untuk menyelesaikan masalah tersebut, memberikan dukungan dalam hubungan kerja yang produktif. Penelitian Bakar dan Mustaffa (2013) menggunakan karakteristik-karakteristik komunikasi organisasi yang mengacu pada Communication Satisfaction Questionnaire (CSQ), yaitu: (1)Arus informasi, (2) Iklim Komunikasi, (3) Karakteristik Pesan, (4) Struktur
Komunikasi , (5) Group Bond, (6) Respect.

Berdasarkan penjelasan diatas penelitian ini menggunakan indikator komunikasi organisasi yang didasarkan pada jenis komunikasi organisasi Arni (2007:107) yaitu Downward communication atau Komunikasi kepada bawahan, Upward communication atau komunikasi kepada atasan, Horizontal communication atau komunikasi horizontal atau komunikasi antar rekan kerja, hal tersebut didukung dengan penelitian sebelumnya yang menggunakan jenis komunikasi organisasi sebagai indikator komunikasi organisasi yaitu Arni dalam (Juita 2013,Mardianto 2004, Mustika 2013, Putri 2013,Purwanto 2011).

\section{Kinerja Karyawan}

Setiap perusahaan pasti menginginkan kinerja yang baik dari karyawan-karyawanya, karena dengan begitu target yang ingin dicapai dapat dipenuhi. Dalam interaksi sehari-hari, antara atasan dan bawahan, berbagai asumsi dan harapan lain muncul. Ketika atasan dan bawahan membentuk asumsi dan harapan mereka sendiri, akan muncul perbedaan-perbedaan. Hal inilah yang akhirnya berpengaruh pada kinerja. Kinerja adalah hasil seseorang secara keseluruhan selama periode tertentu di dalam melaksanakan tugas, seperti stadar hasil kerja, target atau sasaran atau kriteria yang telah ditentukan terlebih dahulu dan telah disepakati bersama menurut(Rivai dan Baswri, 2010:481).

Kinerja (performance) mengacu kepada kadar pencapaian tugas-tugas yang membentuk sebuah pekerjaan 


\section{BISMA - Bisnis dan Manajemen -Volume 8 No. 2 Februari 2016}

karyawan, kinerja merefleksikan seberapa baik seorang karyawan memenuhi persyaratan sebuah pekerjaan. Supaya organisasi berfungsi secara efektif, maka organisasi diharapkan dapat memikat, sehingga karyawan dapat bertahan dan dapat melakukan tugas serta peran mereka dengan baik.

Berbagai macam definisi kinerja (performance), misalnya Mith dalam Suhartono (2010:07), menjelaskan secara psikologis, kinerja merupakan tingkah seseorang, sehingga menghasilkan sesuatu yang menjadi tujuan dari pekerjaanya. Keberadaan kinerja pada dasarnya dipengaruhi oleh 2 faktor, yang pertama yaitu faktorfaktor individu dan kedua yaitu faktor kondisi atau situasi individu bekerja.

Anwar Prabu Mangkunegara (2009:67) dalam bukunya Manajemen Sumber Daya Manusia Perusahaan, mengemukakan pengertian kinerja sebagai berikut: "Kinerja adalah hasil kerja secara kualitas dan kuantitas yang dicapai oleh seorang karyawan dalam melaksanakan tugasnya sesuai dengan tanggung jawab yang diberikanya".

Peneliti juga akan mengemukakan tentang definisi kinerja karyawan menurut Bernandin \& Russel (2008:135) yang dikutip oleh Faustino cardoso gomes dalam bukunya yang berjudul Human Resource Management, Performance adalah catatan yang dihasilkan dari fungsi suatu pekerjaan tertentu atau kegiatan selama periode waktu tertentu.

Mangkunegara

(2009:09), mengatakan bahwa kinerja adalah prestasi kerja atau hasil kerja (output) baik kualitas maupun kuantitas yang dicapai persatuan periode waktu dalam melaksanakan tugas kerjanya sesuai dengan tanggung jawab yang diberikan kepadanya.

Simanjutak (2010:10), kinerja setiap orang dipengaruhi oleh banyak faktor yang dapat digolongkan pada 3 kelompok, yaitu Kompetensi Individu yang wujudnya adalah etos kerja, dukungan organisasi yang berupa budaya organisasi dan iklim organisasi yang berupa budaya organisasi dan iklim organisasi serta dukungan manajemen berupa Kepemimpinan atau keteladan Perilaku Pimpinan.

Pengertian-pengertian tersebut dapat ditarik hubungan kausal bahwa ada hubungan yang erat antara kinerja individu dengan kinerja organisasi. Dengan kata lain, apabila kinerja perorangan baik mak kemungkinan besar kinerja organisasi juga akan baik. Kinerja setiap individu akan baik jika dia mempunyai keahlian (skill) yang tinggi, bersedia bekerja karena digaji sesuai dengan perjanjian, dan mempunyai harapan masa depan yang lebih baik.

Indikator Kinerja Veitzel Rivai 2004:309 dalam yuliawan(2012) yaitu: (1) Kemampuan kerja, (2) Kualitas kerja, (3) Kreativitas kerja, (4) Disiplin kerja, (5) Tingkat kejujuran, (6) Sikap, (7) Loyalitas terhadap pekerjaan, (8) Motivasi, (9)Kompensasi, Lingkungan kerja, (11) Gaji.

Indikator tersebut dipilih karena objek penelitian dari Veitzel Rivai 2004:309 dalam yuliawan(2012) samasama bergerak dibidang manufaktur, selain itu indikator tersebut dapat 
memenuhi kriteria pengukuran kinerja karyawan yang dikemukakan oleh Moehariono (2012:34)

\section{Budaya dan Kinerja Karyawan}

Penelitian yang dilakukan Herlista (2013) mengemukakan hasil penelitianya di PT. PLN Persero Area Semarang bahwa terdapat pengaruh antara budaya organisasi terhadap kinerja karyawan adalah terbukti berpengaruh positif dan signifikan. Wirda dan azra (2007) yang melakukan penelitian pada karyawan Polteknik Negeri Padang mengemukakan bahwa budaya organisasi berpengaruh positif dan signifikan terhadap kinerja karyawan.

Sedangkan perbedaan hasil penelitian dikemukakan oleh Lina (2014) yang melakukan penelitian pada kinerja Biro Universitas Muhammadiyah Sumatera bahwa budaya organisasi tidak berpengaruh signifikan terhadap kinerja karyawan

Komunikasi Organisasi dan Kinerja Karyawan

Penelitian yang dilakukan Akbar (2015) mengemukakan hasil penelitianya pada karyawan di Bank Jatim Cabang Malang bahwa pengaruh variabel komunikasi organisasi berhubungan secara siginifikan terhadap kinerja.

Sismona (2015) penelitian ini bertujuan untuk membuktikan besarnya pengaruh antara komunikasi orgnaisasi terhadap kinerja karyawan, hasil penelitian ini menyebutkan bahwa komunikasi organisasi berpengaruh sangat signifikan terhadap kinerja, dengan indikator komunikasi yaitu saluran formal, struktur wewenang, spesialisasi kerja, kepemilikan informasi.

Namun penelitian lain yang dilakukan oleh Prabawa (2013) penelitian yang dilakukan di PT. TWC Borobudur, Prambanan dan Ratu Boko menunjukkan bahwa komunikasi organisasi tidak berpengaruh siginifikan terhadap kinerja karyawan. Dengan indikator komunikasi organisasi yaitu komunikasi kebawah, komunikasi keatas, komunikasi horizontal, komunikasi lintas saluran dan indikator kinerja yang digunakan yaitu kejelasan tugas, kejelasan hasil dan waktu yang diperlukan.

Berdasarkan uraian diatas, maka hipotesis yang dapat diambil adalah:

H1: Budaya Organisasi berpengaruh signifikan terhadap kinerja karyawan

H2:Komunikasi Organisasi berpengaruh signifikan terhadap kinerja karyawan

H3:Budaya Organisasi dan Komunikasi

Organisasi berpengaruh secara simultan terhadap kinerja karyawan

\section{METODE PENELITIAN}

Pada penelitian ini menggunakan metode penelitian kuantitatif. Jenis teknik statistik yang digunakan adalah statistik inferensial. Digunakannya teknik statistik inferensial ini dikarenakan statistik inferensial adalah teknik statistik yang berhubungan dengan analisis data untuk penarikan kesimpulan atas data (Santosa dan Ashari, 2005:2).

Populasi dalam penelitian ini adalah 500 karyawan PT.Shoei Surabaya. Sampel pada penelitian ini adalah 80 karyawan dengan 


\section{BISMA - Bisnis dan Manajemen -Volume 8 No. 2 Februari 2016}

menggunkan Random Sampling sample tap divisi.

Penelitian ini menggunakan tiga variabel yang terdiri dari dua variabel bebas yaitu budaya organisasi dan komunikasi organisasi. selanjutnya variabel terikat yaitu kinerja karyawan.

Untuk mengukur budaya organisasi menggunakan indikator dari Robbins dan Judge (2008:256) yang terdiri dari: (1) Inovasi dan keberanian mengambil resiko, (2) Perhatian terhadap hal-hal rinci, (3) Orientasi hasil, (4) orientasi orang, (5) Orientasi tim, (6) Agresifitas, (7) Stabilitas. Selanjutnya untuk mengukur komunikasi organisasi menggunakan komunikasi organisasi Arni (2007:107) yaitu (1) Downward communication atau Komunikasi kepada bawahan, (2) Upward communication atau komunikasi kepada atasan, (3) Horizontal communication atau komunikasi horizontal atau komunikasi antar rekan kerja.

Kinerja karyawan adalah kemampuan karyawan pada PT. X Surabaya, yang dinilai secara kualitas dan kuantitas dalam melaksanakan tugasnya sesuai dengan tanggung jawab yang diberikan kepadanya. Indikator kinerja karyawan bagian instalasi pada PT. X Surabaya dalam penelitian ini diukur berdasarkan indikator penilaian kinerja karyawan yang digunakan adalah penilaian kinerja dari Veitzel Rivai 2004:309 dalam yuliawan (2012), yaitu: (1) kemampuan kerja, (2) kualitas kerja, (3) kretifitas kerja, (4) disiplin kerja,
(5) tingkat kejujuran, (6) sikap, (7) loyalitas, (8) motivasi, (9) kompensasi, (10) lingkungan kerja, (11) Gaji.

Teknik pengumpulan data yang digunakan dalam penelitian ini adalah observasi tak terstruktur, interview tak langsung menggunakan kuesioner. Skala pengukuran yang digunakan adalah skala likert. Skala likert adalah skala pengukuran yang digunakan untuk mengukur sikap, pendapat, dan persepsi seseorang atau sekelompok orang tentang fenomena sosial (Sugiyono, 2012:93).

Teknik analisis data menggunakan regresi linier berganda dengan aplikasi SPSS 20 sebagai alat olah dan analisa data. Setelah melalui uji validitas, diketahui bahwa seluruh item pernyataan dari budaya organisasi dan komunikasi organisasi sebagai variabel independent dikatakan valid karena nilai $\mathrm{R}$ hitung diatas nilai $\mathrm{R}$ tabel yaitu 0,279 dan dari seluruh pernyataan kinerja karyawan dinyatakan yang valid maka instrumen pernyataan yang digunakan dapat digunakan untuk mengukur variabel-variabel dengan tepat. Sementara uji reliabilitas menunjukkan bahwa nilai cronbach's alpha dari ketiga variabel diatas 0,60 maka instrumen yang digunanakan reliabel atau dapat dipercaya untuk digunakan dalam penelitian (Santosa dan Ashari, 2005:251).

\section{HASIL DAN PEMBAHASAN}

Setelah melakukan pengujian terhadap validitas dan reliabilitas dari 


\section{Jujung Dwi Marta dan Dewie Triwijayanti - Pengaruh Budaya Organisasi ...}

instrumen yang digunakan pada penelitian ini yang menghasilkan sebuah kesimpulan bahwa instrumen yang digunakan pada penelitian ini valid serta reliabel atau tepat dan dapat dipercaya maka langkah selanjutnya yang akan ditempuh untuk meyakinkan bahwa persamaan regresi yang dihasilkan pada penelitian ini valid dan dapat digunakan untuk memprediksi hasil penelitian serta memenuhi asumsiasumsi umum yang terdapat pada analisis regresi linier berganda dan statistik parametrik, adalah dengan melakukan uji asumsi klasik yang terdiri dari uji normalitas, uji multikolonearitas, heteroskedastisitas, uji liniearitas. Dilakukan uji asumsi klasik yang terdiri dari uji normalitas dan uji heteroskedastis. Berdasarkan hasil analisis dengan menggunakan PASW SPSS 20, didapatkan analisis grafik PPlot dengan melihat normal probability plot yang membandingkan distribusi kumulatif dan distribusi normal. Berdasar kan analisis grafik P-Plot menunjukkan bahwa data berdistribusi normal karena tertelat disekitar garis diagonal. Selanjutnya uji multikolonearitas dari persmaan regresi pada penelitian ini dengan melihat angka Tolerance atau dengan melihat nilai VIF dan hasil analisis multikolonearitas dari budaya organisasi dan komunikasi organisasi menghasilkan skor Tolerance 0,996 yang mendekati nilai 1 yang artinya tidak terjadi multkolonearitas. hasil analisis uji heteroskedastisitas Glejser bahwa tidak terjadi heteroskedastis, nilai $t_{\text {hitung }}$ lebih kecil dari $t_{\text {tabel, }}$ diketahui bahwa budaya organisasi dengan nilai $\mathrm{t}_{\text {hitung }}$ sebesar $-0,677$ lebih kecil dari 2,00 dan nilai signifikansi 0,501 lebih besar dari 0,05 dan komunikasi organisasi Hal nilai $t_{\text {hitung }}$ lebih kecil dari $t_{\text {tabel, }}$ diketahui bahwa budaya organisasi dengan nilai $t_{\text {hitung }}$ sebesar 0,338 lebih kecil dari 2,00 dan nilai signifikansi 0,737 lebih besar dari 0,05 ini menjelaskan bahwa tidak terjadi gejala heteroskedastis.

Langkah selanjutnya adalah uji linearitas dari persamaan regresi pada penelitian ini dengan melihat nilai signifikansi linierity harus $<0,05$ dan deviation from linearity harus $>0,05$ dengan tujuan untuk melihat linear tidaknya variabel penelitian yang digunakan sebagai syarat anlalisis. Hasil dari analisis ini menunjukkan bahwa nilai sig. Linearity $0,000<0,05$ dan deviation from linearity $0,425>0,05$. Untuk komunikasi organisasi nilai sig. Linearity $0,000<0,05$ dan deviation from linearity $0,127>0,05$, dari hasil diatas dapat disimpulkan bahwa budaya organisasi dan komunikasi organisasi linier terhadap kinerja.

Setelah uji asumsi klasik telah dilakukan langkah selanjutnya adalah dengan melakukan uji pengaruh signifikan (uji t) dan uji signifikan simultan (uji F). Diketahui bahwa koefisien regresi dari variabel budaya organisasi dan komunikasi organisasi adalah signifikan atau budaya organisasi dan komunikasi organisasi berpengaruh signifikan terhadap kinerja karyawan. Hasil temuan ini membenarkan hipotesis yang pertama dan kedua pada penelitian ini yaitu "budaya organisasi berpengaruh terhadap kinerja 


\section{BISMA - Bisnis dan Manajemen -Volume 8 No. 2 Februari 2016}

karyawan" dan "komunikasi organisasi berpengaruh terhadap kinerja karyawan"sekaligus menunjukkan hasil penelitian yang sesuai dengan penelitian sebelumnya tentang budaya organisasi terhadap kinerja.

Dari uji ANOVA atau $\mathrm{F}$ test diatas, didapat $\mathrm{F}$ hitung adalah 45.507 dengan tingkat signifikansi 0,000 . Nilai signifikansi sebesar 0,000 jauh lebih kecil dari 0,05 sehingga model regresi bisa dipakai untuk memprediksi kinerja karyawan atau dapat dikatakan bahwa budaya organisasi dan komunikasi organisasi secara bersama-sama atau secara simultan berpengaruh terhadap kinerja karyawan. Pernyataan ini sekaligus menerima hipotesis ketiga pada penelitian ini yaitu "budaya organisasi dan komunikasi organisasi berpengaruh secara simultan terhadap kinerja karyawan".

Didapatkan angka $\mathrm{R}$ square adalah 0,542 . Hal ini berarti $54,2 \%$ dari variasi kinerja karyawan PT. X Surabaya bisa dijelaskan oleh variabel budaya organisasi dan komunikasi organisasi sedangkan sisanya $(100 \%-54,2 \%=$ $45,8 \%$ ) dijelaskan oleh sebab-sebab yang lain

\section{Pengaruh Budaya Organisasi Terhadap Kinerja Karyawan}

Berdasarkan pengujian penelitian, diperoleh hasil bahwa budaya organisasi berpengaruh positif dan signifikan terhadap kinerja karyawan bagian produksi PT. X Surabaya, sehingga hasil ini menerima hipotesis pertama pada penelitian ini.

Hasil temuan ini juga sesuai dengan teori dari (Safaria, 2004:9) yaitu Budaya organisasi ini dapat membentuk lingkungan yang destruktif atau konstruktif dalam sebuah perusahaan sehingga meningkatkan kinerja karyawan. Hasil temuan sesuai dengan penelitian sebelumnya yaitu penelitian dari Soedjono (2005), Herlista (2013), Wirda dan Azzara (2013), dan Edwardin (2006). Sesuai dengan teori dari Griffin (2007: 176) Sesuai dengan konteks sumber daya manusia pada perusahaan, untuk menghasilkan karyawan yang profesional dengan integritas yang tinggi dalam kinerjanya, diperlukan adanya acuan baku yang diberlakukan oleh suatu perusahaan. Acuan tersebut adalah budaya organisasi yang secara sistematis menuntut karyawan untuk meningkatkan kinerjanya bagi perusahaan.

Temuan kejadian dilapangan yang sesuai dengan anlisis penelitian peneliti pada karyawan PT. X Surabaya bahwa karyawan diharuskan mengikuti budaya organisasi perusahaan "muranogurupu" yang berbasis berpikir secara kelompok. Budaya tersebut dikategorikan dalam tiga bentuk umum budaya pertama yaitu, "kemampuan untuk bekerjasama adalah penting".

Budaya oganisasi PT. X

Surabaya diatas menunjukkan bahwa budaya organisasi yang berbasis kelompok pada kategori budaya pertama sesuai dengan hasil analisis peneliti yaitu indikator orientasi tim yang mengukur tentang kegiatan kelompok karyawan yang memiliki skor pada kategori baik, hal ini menunjukkan bahwa dalam hal kelompok kerja atau tim yang dihasilkan oleh budaya organisasi pada PT. X Surabaya 


\section{Jujung Dwi Marta dan Dewie Triwijayanti - Pengaruh Budaya Organisasi ...}

dikatakan baik, karena dari budaya organisasi perusahaan sendiri sangat menekankan pada kerja tim dalam pekerjaan karyawan. Dari nilai rata-rata indikator orientasi tim tersebut menunjukkan bahwa karyawanpun setuju bahwa dalam pekerjaan mereka kerja tim atau kelompok dianggap penting.

Temuan peneliti tentang kerja tim yang diungkapkan oleh salah satu responden dibagian produksi yang membenarkan tentang kerja tim sangat ditekankan pada PT. X Surabaya, salah satunya adalah mengenai target kerja yang dibebankan pada grup kerja untuk mencapai target produksi. Jadi solidaritas antar karyawan terjalin dengan sangat baik untuk masalah kerja bahkan sampai diluar kerja karena mereka terbiasa menyelesaikan tugas bersama.

Berdasarkan masalah diatas peneliti menyimpulkan bahwa kerja tim sangatlah penting untuk menjalin hubungan baik antar rekan kerja yang berguna baik untuk perusahaan maupun karyawan itu sendiri.

Budaya kedua, "tidak ada atas dan bawah dalam bekerja" hal tersebut berlaku untuk karyawan baru yang baru lulus atau fresh graduate, mereka dididik untuk terbiasa dengan pekerjaan level terendah, salah satu contohnya apabila seorang karyawan baru lulusan perguruan tinggi bisa saja diminta melap meja, memfotocopi, merapikan file, yang akan dianggap seperti pesuruh atau sedang dikerjai, namun hal tersebut sudah biasa di perusahaan karena perusahaan menekankan pada kemandirian. Sebagus apapun kualitasnya, seorang individu harus belajar dari bawah dengan tujuan karyawan tersebut dapat mengenal sistem mulai dari sehingga karyawan akan terbiasa dan mengenal pekerjaan mulai dari level bawah.

Penjelasan tentang budaya organisasi PT. X yang kedua ditemukan hubungan dengan kuisioner pada indicator orientasi orang yang memiliki skor dengan nilai dikategorikan baik yang diartikan bahwa karyawan setuju dengan budaya perusahaan tersebut dan mau menjalankan apa yang perusahaan arahkan.

Budaya organisasi ketiga "satu perusahaan seumur hidup", tempat bekerja dibuat menjadi rumahnya atau desanya yang tak terpisahkan, karena perusahaan menganggap karyawan seperti investasi. Jadi dengan mendidik dari bawah, memberikan pelatihan dan sebagainya, karyawan diharapkan mengerti sehingga loyal dengan perusahaan dan bisa mengembangkan diri. Di mata perusahaan apabila seseorang adalah tipe kutu loncat atau suka berpindah-pindah perusahaan maka akan mencoreng profesionalitas individu itu sendiri, budaya ini dapat dijelaskan dengan melihat hail skor indikator perhatian terhadap detail dengan skor yang dikategorikan baik.

Setelah melihat hasil analisis dari budaya organisasi yang berpengaruh signifikan positif terhadap kinerja dan temuan dilapangan disimpulkan bahwa penyebab menurunya kinerja karyawan bukanlah budaya organisasi melainkan dipengaruhi oleh faktor lain, hal tersebut dapat dilihat dari analisis yang menunjukkan bahwa budaya organisasi 


\section{BISMA - Bisnis dan Manajemen -Volume 8 No. 2 Februari 2016}

berpengaruh positif terhadap kinerja dan untuk penyebab menurunya kinerja disimpulkan oleh peneliti dipengaruhi oleh faktor lain seperti gaji, motivasi, perubahan kepemimpinan yang dalam angka sebesar $45,8 \%$.

\section{Pengaruh Komunikasi Organisasi Terhadap Kinerja Karyawan}

Berdasarkan pengujian penelitian, diperoleh hasil bahwa komunikasi organisasi berpengaruh positif dan signifikan terhadap kinerja karyawan produksi PT. X Surabaya, hasil ini menerima hipotesis kedua pada penilitian ini. Hasil temuan ini sesuai dengan penelitian sebelumnya yang dilakukan Akbar (2015) dan Sismona (2015) dan sesuai dengan teori dari Sukoco (2007: 52) menjelaskan bahwa tanpa adanya komunikasi yang efektif, orang yang dalam konteks penelitian ini adalah karyawan akan sulit memahami dan mengimplementasikan isi atau perintah dari informasi yang telah disampaikan untuk menunjang kinerja yang maksimal.

Setiap perusahaan, komunikasi organisasi mempunyai peranan sentral. Ini terutama berlaku dalam efektifitas organisasi begitu juga pada PT. X Surabaya. Proses dan pola komunikasi merupakan sarana yang diperlukan untuk mengkoordinasi dan mengarahkan kegiatan karyawan ketujuan dan sasaran organisasi. Komunikasi organisasi terdiri persepsipersepsi atas unsur-unsur tersebut terhadap komunikasi. Pengaruh ini didefinifisikan, disepakati, dikembangkan, dan dikokohkan secara berkesinambungan melalui interaksi dengan anggota organisasi lainya.
Pengaruh ini menghasilkan pedoman bagi keputusan-keputusan dan tindakantindakan individu dan mempengaruhi pesan-pesan mengenai organisasi

Hasil dari kuisioner yang diisi oleh karyawan produksi PT. X Surabaya tentang indikator yang digunakan untuk mengukur komunikasi organisasi memiliki skor yang dikategorikan baik. hal ini menunujukkan indikator komunikasi yang digunakan sesuai dan disetujui oleh karyawan PT. X Surabaya.dari hasil skor rata-rata indikator tersebut terlihat bahwa komunikasi antar bawahan dengan atasan terjalin dengan baik, hal itu terlihat dari tanggapan responden untuk indikator penyampaian masalah kerja yang terjadi kepada atasan yang memiliki skor yang dikategorikan baik.

Selanjutnya untuk komunikasi kebawah karywan memberikan skor dengan rata-rata baik seperti instruksi tugas, rasional, idiologi informasi dan balikan yang menunjukkan bahwa karyawan memang setuju bahwa atasan memberikan tugas dengan menjelaskan secara jelas tugas yang diberikan dan menjelaskan hubungan tugas tersebut dengan tujuan organisasi, selain itu karyawan juga mengungkapkan bahwa atasan juga memberikan motivasi untuk tugas yang diberikan agar dapat menyelesaikan tugas yang diberikan.

Hal ini yang membuat hasil temuan pada penelitian ini menunjukkan bahwa komunikasi organisasi berpengaruh positif dan signifikan terhadap kinerja karyawan produksi PT. X Surabaya karena apabila komunikasi organisasi yang baik tidak 


\section{Jujung Dwi Marta dan Dewie Triwijayanti - Pengaruh Budaya Organisasi ...}

dipertahankan maka kinerja karyawan akan menurun.

Setelah melihat hasil analisi dari komunikasi organisasi yang berpengaruh signifikan positif terhadap kinerja dan temuan dilapangan disimpulkan bahwa penyebab menurunya kinerja karyawan bukanlah budaya organisasi melainkan dipengaruhi oleh faktor lain, hal tersebut dapat dilihat dari analisis yang menunjukkan bahwa komunikasi organisasi berpengaruh positif terhadap kinerja dan untuk penyebab menurunya kinerja disimpulkan oleh peneliti dipengaruhi oleh faktor lain seperti gaji, motivasi, perubahan kepemimpinan yang dalam angka sebesar $45,8 \%$

Pengaruh Budaya Organisasi dan Komunikasi Organisasi Terhadap Kinerja Karyawan

Berdasarkan pengujian penelitian, diperoleh hasil bahwa budaya organisasi dan komunikasi organisasi secara bersama-sama atau secara simultan berpengaruh terhadap kinerja karyawan.

Beberapa temuan yang terjadi pada karyawan PT. X Surabaya khususnya jika dilihat dari variabel budaya organisasi mereka menunjukkan bahwa solidaritas antar rekan kerja diantara mereka terjalin sangat kuat. Jika salah satu rekan sedang mendapat masalah kerja maupun diluar kerja kondisi maka rekan yang lain mencoba mengajak berkomunikasi untuk mencari solusi masalah tersebut dengan memberi semangat, motivasi ataupun bantuan materi yang dikumpulkan bersama-sama antar rekan kerja.

Kegiatan salah satu rekan yang mencoba mengajak komunikasi rekannya yang sedang memiliki masalah dalam sebuah kelompok kerja atau budaya organisasi pada poin kerja tim merupakan suatu bentuk komunikasi horizontal atau komunikasi antar rekan kerja untuk menjalin hubungan yang baik dan sebagai bentuk solidaritas antar rekan kerja untuk mencapai kinerja yang baik dengan membantu menyelesaikan masalah rekan kerja atau masalah yang terjadi dalam kelompok untuk diselesaikan bersama, hal ersebut sangat berguna untuk karyawan dan perusahaan.

Berdasarkan hal tersebut, maka hipotesis ketiga pada penelitian ini dapat diterima. Hasil temuan ini sejalan dengan hasil penelitian dari Paisal dan Anggraini (2010), Erisna dkk (2012), dan Tarmizi dkk (2012)

\section{KESIMPULAN}

Berdasarkan hasil analisis dan uji hipotesis, maka dapat diambil kesimpulan sebagai berikut:

1. Budaya organisasi berpengaruh signifikan positif terhadap kinerja karyawan pada PT. X Surabaya.

2. Komunikasi organisasi berpengaruh sigifikan positif terhadap kinerja karyawan pada PT. X Surabaya.

3. Budaya organisasi dan komunikasi organisasi secara simultan mempunyai pengaruh yang signifikan terhadap kinerja karyawan PT. X Surabaya bagian produksi.

Bagi PT X Surabaya peneliti menyarankan bahwa budaya organisasi yang ada diperusahaan sudah baik dan harus terus dipertahankan dengan cara pemimpin selalu memberikan contoh 


\section{BISMA - Bisnis dan Manajemen -Volume 8 No. 2 Februari 2016}

kepada bawahan bahwa pemimpin selalu menjalankan budaya organisasi perusahaan. Pada budaya pertama yaitu "kemampuan bekerjasama adalah penting" dipertahankan dengan perusahaan tetap memberikan tugas kerja dengan bentuk kelompok selain untuk mempertahankan budaya juga untuk meningkatkan hasil kerja yang lebih baik. Selanjutnya budaya kedua yaitu "tidak ada atasan dan bawahan" dipertahankan dengan tetap menjalankan tradisi untuk karyawan baru tetap memperkenalkan karyawan tersebut pada pekerjaan yang paling bawah.

Selanjutnya budaya ketiga "satu perusahaan seumur hidup" dipertahankan dengan meningkatkan kenyamanan kerja pada faktor lingkungan kerja sehingga karyawan akan merasa nyaman dalam bekerja yang juga dapat membuat motivasi kerja karyawan meningkat.

Untuk budaya organisasi dan komunikasi organisasi yang baik yang ada di perusahaan yang tidak diimbangi dengan kinerja karyawan yang baik pula harus segera ditanggapi untuk menyelesaikan masalah tersebut dengan memeperhatikan factor-faktor sepertigaya kepemimpinan, motivasi kerja, kompensasi, lingkungankerja dan gaji karena dari hasil analisis diketahui bahwa penyebab menurunya kinerja bukanya disebabkan oleh budaya dan komunikasi. Selanjutnya untuk komunikasi organisasi yang ditunjukkan dengan hasil analisa peneliti bahwa komunikasi organisasi yang ada di perusahaan sudah baik dan harus terus dipertahankan dan ditingkatkan untuk kebaikan perusahaan dan karyawan

Bagi penelitian yang akan datang diharapkan untuk dapat menemukan variabel-variabel tambahan yang mampu menjelaskan atau mempengaruhi kinerja karyawan,Budaya organisasi dan komunikasi organisasi seperti lingkungan kerja, motivasi kerja,gaji, motivasi, kreativitas kerja,variabel stres kerja, dankompensasi yang juga dapat menjelaskan kinerja karyawan sebagai variabel tambahan atau variabel pendukung.

\section{REFERENSI}

Akbar, Mirza Asmi. 2015. Pengaruh Gaya Kepemimpinan Transformasional dan Komunikasi Organisasi Terhadap Kinerja Karyawan: Studi pada Karyawan Bank Jatim Cabang Malang, Jurnal Administrasi Bisnis (JAB).

Akbar, Rizza Muhammad. 2013. Pengaruh Budaya Organisasi Terhadap Employee Engagement (Studi Pada Karyawan PT. Primatexco Indonesia di Batang).Journal of Science and Industrial Psychology. Vol. 2. No. 1.ISSN 2252-6838.

Arikunto, S.,2006. Prosedur Penelitian Suatu Pendektan Praktik. Jakarta: Rineka Cipta.

Arni, Muhammad. 2001. Komunikasi Organisasi. Jakarta: PT. Bumi Aksara.

Arni, Muhammad. 2007. Komunikasi Organisasi. Jakarta: PT. Bumi Aksara. 
Arni, Muhammad. 2009. Komunikasi

Organisasi. Jakarta: Bumi Aksara.

Atmosoeprapto, Krisdarto. 2009.

Produktivitas Aktualitas Budaya

Perusahaan. Jakarta. PT. Elex

Media Komputindo Kelompok Gramedia.

Awadh dan Saad. 2013. Impact of

Organizational Culture on

Employee Performance.

International Review of

Management and Business

Research vol. 2 issue.1. ISSN: 2306-9007.

www.irmbjournal.com diakses

tanggal 1 agustus 2015.

Ayatullah. 2003. Komunikasi dan Organisasi. Yogyakarta: Fakultas

Ekonomi

Universitas

Muhammadiyah Yogyakarta.

Bachtiar, Doni. 2012. Pengaruh Lingkungan Kerja Terhadap

Kinerja Karyawan. Management Analysis Journal. $\quad$ ISSN:

2252-6552.

$1-6$.

www.irmbjournal.com, diakses tanggal 3 Desember 2015.

Bernardin dan Keane. 2008. Enam

Kriteria Primer Penentuan

Kinerja. Jakarta: Bumi Aksara.

Brahmasari, Ida Ayu dan Agus

Suprayitno. 2008. Pengaruh

Motivasi Kerja, kepemimpinan

dan Budaya Organisasi

Terhadap Kepuasan Kerja

Karyawan serta Dampaknya

pada Kinerja Perusahaan.

Jurnal Manajemen dan

Kewirausahaan, Vol.10,

No.2.(www.google.com/,

Diakses 5 Agustus 2015).

P124-135.
Cascio, wayne F. 2009. Managing

Human Resources: Productifity, Qualty of Work LifeProfits, 4'ed. McGraw Hill. New York

Dimitrious, Belias. 2014.

Organizational Culture and Job

Satisfaction, In Banking Sector- A

Review. Journal of Human

Resources Management. Vol.3,

Issue 1. (www.google.com/,

Diakses 12 Agustus 2015).p1536.

Djokosantoso Moeljono.2003. Budaya

Korporat dan Keunggulan

Korporasi (edisi revisi). Jakarta:

PT. Elex Media Komputindo.

Djokosantoso Moeljono. 2006.

Cultured. Budaya Organisasi

Dalam Tantangan. Jakarta: PT.

Pustaka Binaman Pressindo.

Edwardin. 2006. Analisis Pengaruh

Kompetensi

Komunikasi,Kecerdasan

Emosional,

Dan

BudayaOrganisasi Terhadap

Kinerja Karyawan(Studi Pada Pt

Pos Indonesia (Persero) Se Kota

Semarang)

Femi.2014. The Impact of Communication on Workers' Performance in Selected Organisations in Lagos State, Nigeria. IOSR Journal Of Humanities And Social Science (IOSR-JHSS) Volume 19, Issue 8, Ver. II (Aug. 2014), PP 75-82 e- ISSN: $2279-$ 0837, p-ISSN: 2279-0845. www.iosrjournals.org. Diakses tanggal 3 Agustus 2015.

Ferdinand, Agusty. 2006. Metode Penelitian Manajemen. Edisi 
Kedua. Semarang : Badan Penerbit Universitas Ponorogo.

Ghasemi, Mahboobeh. 2013. The Impact of "Organizational Culture" on "Job Satisfaction" and "Employee Performance";Evidence From Commercial Banks of the Pune City. (http://google.com/ Diakses 5 Agustus 2015). P386-397.

Ghozali, Imam. 2013. Aplikasi Analisi Multivariate dengan program IBM SPSS 2.1. Edisi 7 Cetakan 8. Semarang : Badan Penerbit Universitas Ponorogo.

Griffin, Ricky W. 2004. Manajemen Personalia. Edisi Ketujuh. Jakarta: Erlangga.

Griffin, Ricky W. 2006. Business. Edisi kedelapan. Jakarta: Erlangga.

Hamdi, Asep Saepul. 2014. Metode Penelitian Kuantitatif Aplikasi dalam Pendidikan. Edisi satu. Yogyakarta: Deepublish (CV Budi Utama)

Hasibuan. 2010. Manajemen Sumber Daya Manusia. Jakarta: Bumi Aksara.

Handoko, T. Hani. 2010. Manajemen Personalia dan Sumber Daya Manusia. Edisi dua. Yogayakarta: BPFE-Yogayakarta

H. A. W Widjaya. 2000. Ilmu Komunikasi, Pengantar Studi. Jakarta: Rieneka Cipta.

Herlista, Joko dan Dewi. 2013. Pengaruh Budaya Organisasi, Komunikasi Organisasi TerhadapKinerja Karyawan Melalui Motivasi Sebagai Variabel Intervening Pada PT. Pln (Persero) Area Semarang.
Kiswanto, M. 2010. Pengaruh Kepemimpinan dan Komunikasi Terhadap Kinerja karyawan Kaltim Pos Samarinda. Jurnal Eksis. Vol.5 No.1, Maret 2010: 1267-1439.

Lina, Dewi. 2014. Analisis Pengaruh Kepemimpinan dan Budaya Organisasi Terhadap Kinerja Pegawai dengan Sistem Reward Sebagai Variabel Moderating: Pegawai Biro UMSU Universitas Muhammadiyah Sumatera Utara. Jurnal Riset Akuntansi dan Bisnis. Vol.14, No. 1. (http://ijcrb.webs.com/, diakses 12 September 2015).p18-21.

Lita, Dewi. 2012. Analisis Pengaruh Kepemimpinan dan Budaya Organisasi Terhadap Kinerja Pegawai dengan Sistem Reward Sebagai Variabel Moderating. Skripsi: Fakultas Ekonomi Universitas Airlangga.

Luthans, J. Fred. Perilaku Organisasi. Edisi Sepuluh. Terjemahan oleh Vivin Andhika Yuwono,dkk. 2006 .Yogyakarta:ANDI.

Mangkunegara, A P. 2009. Manajemen sumber daya manusia Perusahaan. Bandung: PT. Remaja Rosdakarya Offset.

Mathis, Robert L. dan John H. Jackson. 2006. Manajemen Sumber Daya Manusia, Edisi Sepuluh.Jakarta: Salemba Empat, Moehariono, 2009. Pengkuran Kinerja Berbasis Kompetens. Bandung: Penerbit Ghalia Indonesia.

Moeljono, Djokosantoso. 2005. Budaya Organisasi dalam Tantangan 
(cetakan kedua). Jakarta: PT. Elex Komputindo

Mulyasa, 2009. Manajemen Kinerja Teoti dan Aplikasi. Bandung: Alfabeta.

Pace, R. Wayne dan Faules, Don F. 1998. Komunikasi Organisasi Strategi Meningkatkan Kinerja Perusahaan, terjemahan Deddy Mulyana, Bandung: PT Remaja Rosdakarya

Purwanto, Soni Bagus. 2011. Pengaruh Komunikasi, Motivasi dan Kepuasan Kerja terhadap Kinerja Karyawan (Studi pada Proyek Pondasi Tower Timor Leste PT. Cahaya Inspirasi Indonesia). Jurnal Aplikasi Manajemen. Vol. 11, No. 1. ISSN 1693-5241.

Putri, Nia Septiana. 2014. Komunikasi Organisasi dalam

Mensosialisasikan Budaya Organisasi Prinsip 46 Pt. Bank Negara Indonesia (Persero)Tbk. Kantor Cabang Utama Samarinda. eJournal Komunikasi, Vol.2, No.2. 285-399.

Prabawa. 2013. Pengaruh Komunikasi Organisasi dan Gaya Kepemimpinan Terhadap Kinerja Karyawan dengan Budaya Organisasi Sebagai Variabel Intervening: Studi Kasus pada PT. TWC Borobudur, Prambanan dan

Ratu Boko. (Skripsi). (www.google.com/, diakses 12 September 2015) p9-12. Ramli. 2009. Pengaruh Komunikasi Organisasi Terhadap Efektivitas Kinerja Pada PT.Radio Memora Anoa Indah.(www.google.com/, diakses 12 September 2015) p6770

Riani, Asri Laksmini. 2011. Budaya Organisasi. Cetakan pertama. Yogyakarta: Graha Ilmu.

Rivai, Veihzal. 2006. Manajemen Sumber Daya Manusia, edisi 10, jilid 1. Jakarta: Indeks

Robbins, Stephen. 2010. Manajemen. Jakarta: Erlangga

Robbins, Stephen P. 2008. Perilaku Organisasi Edisi 12 Buku 1 dan 2. Jakarta: Penerbit Salemba Empat.

Ruky, Achmad S. 2001. Sistem Manajemen Kinerja (Performance Management System). Edisi satu. Jakarta: Gramedia Pustaka Utama.

Freddy, Rangkuti. 2011. Riset Pemasaran. Cetakan ke 10. Jakarta: PT. Gramedia.

Sanusi, Anwar. 2011. Metodologi Penelitian Bisnis. Jakarta : Salemba Empat.

Sari, Triana Kartika. 2013. Pengaruh Budaya Organisasi Terhadap Komitmen Organisasi Melalui Kepuasan Kerja Karyawan. Jurnal Ilmu Manajemen. Vol.1 No.3. (http://ejournal.unesa.ac.id/, diakses 22 Agustus 2015).p827836.

Safaria, $\quad$ Triantoro. 2004. Kepemimpinan. Yogyakarta: Penerbit Graha Ilmu.

Simamora, Henry. 1997. Manajemen Sumber Daya Manusia. Yogyakarta: STIE. YKPN.

Simamora, Henry. 2012. Manajemen Sumber Daya Manusia. Jakarta: Bumi Aksara.

Sinaga. 2009. Pengaruh Budaya Organisasi terhadap Kinerja 
Pegawai pada sekretariat daerah Kabupaten Dairi Sumatera Utara.

Sugiyono. 2010. Metode Penelitian Kuantitatif Kualitatif dan $R \& D$,. Alfabeta, Bandung

Sunadji, Eka Afnan Troena, Surachman, Armanu. 2013. The Role of Organizational Culture, Leadership, Communication and Job Satisfaction on Employee Performance (Study on Public Enterprise of Water Resource Management of Ministry StateOwned Enterprise). Journal of Business and Behavioral Sciences. Vol. 3, No.2 (www.google.com/, diakses 12 Agustus 2015). p34-42.

Sunyoto, Danang. 2013. Teori, Kuisioner, dan Analisis Data Sumber Daya Manusia (Praktik Penelitian). Yogyakarta : CAPS (Center for Academic Publishing Service).

Surya, Dharma. 2010. Manajemen Kinerja. Jakarta: Pustaka Pelajar.

Soedjono. 2005. Pengaruh Budaya Organisasi Terhadap Kinerja Organisasi dan Kepuasan Kerja Karyawan pada Terminal Penumpang Umum di Surabaya. Jurnal Manajemen dan
Kewirausahaan, Vol. 7 No.1. Maret 2005:22-47.

Hessel, Nogi S. Tangkilisan, 2007. Manajemen Publik,: Grasindo, Jakarta

Taurisa, Chaterina Melina dan Intan Ratnawati. 2012. Analisi Pengaruh Budaya Organisasi dan Kepuasan Kerja Terhadap Komiten Organisasional Dalam Meningkatkan Kinerja kRyawan (Studi pada PT. Sido Muncul Kaligawe Semarang). Jurnal Bisnis dan Ekonomi, Vol.19, No.2. (www.google.com/,Diakses 5 Agustus 2015).p170-187

Umar, Husein, 2008. Desain Penelitian MSDM dan Perilaku Karyawan: Paradigma Positivistik Berbasis Pemecahan Masalah. Jakarta: Raja Grafindo Persada.

Wirda dan Azra. 2007. Pengaruh Budaya Organisasi Terhadap Kinerja Karyawan Politeknik Negeri Padang. Jurnal Ekonomi dan Bisnis, 2, 2248.

Yuliawan, Eko. 2012. Pengaruh Stres Kerja dan Konflik Terhadap Kinerja pada PT. Pindad Bandung. Jurnal Wira Ekonomi Mikro Skil. Vol. 2, No. 